\title{
Pengaruh Penerapan Anggaran Berbasis Kinerja dan Pertanggungjawaban Belanja Terhadap Kualitas Laporan Akuntabilitas Kinerja Pegawai Instansi Pemerintah (LAKIP) Badan Pengelola Pajak dan Retribusi Daerah Pemerintah Kota Medan
}

\author{
Fauziah \\ Universitas Sumatera Utara \\ Fauziah.harahap@icloud.com
}

\begin{abstract}
Abstrak
Penelitian ini dilakukan untuk menguji pengaruh penganggaran berbasis kinerja dan penerapan sistem pertanggungjawaban belanja terhadap kualitas laporan pertanggungjawaban kinerja instansi pemerintah daerah, instansi perpajakan dan penerimaan negara Kota Medan secara bersamaan. Sampel dalam Artikel ini adalah Pegawai Badan Pengelolaan Pajak dan Retribusi Daerah Pemerintah Kota Medan yang berjumlah 79 responden. Jenis data yang digunakan dalam Artikel ini adalah data mentah. Alat analisis yang digunakan dalam Artikel ini meliputi uji validitas dan reliabilitas alat Artikel, uji hipotesis klasik dan uji hipotesis dengan analisis linier berganda. Pengujian hipotesis membuktikan bahwa penerapan anggaran berbasis kinerja berdampak positif dan signifikan terhadap kualitas laporan akuntabilitas kinerja instansi pemerintah sampai batas tertentu, sedangkan pertanggungjawaban belanja secara parsial berpengaruh positif dan tidak signifikan terhadap Kualitas Laporan Akuntabilitas Kinerja Instansi Pemerintah Badan Pengelola Pajak dan Retribusi Daerah Pemerintah Kota Medan.
\end{abstract}

Kata Kunci: Penerapan Anggaran Berbasis Kinerja, Pertanggungjawaban Belanja dan Kualitas Laporan Akuntabilitas Kinerja Instansi Pemerintah

\section{PENDAHULUAN}

Semangat reformasi menciptakan warga menuntut pemerintah supaya menaruh perhatian yg benar-benar-benar-benar pada membangun pemerintahan yg bersih (good governance) bebas berdasarkan KKN sebagai akibatnya output 
pelayanan berdasarkan penyelenggara pemerintahan \& pembangunan bisa dinikmati sang bangsa Indonesia. Semangat reformasi tadi sudah melahirkan reformasi keuangan negara menggunakan lahirnya 3 (tiga) paket Undang-undang mengenai Keuangan Negara yaitu Undang-undang Nomor 17 tahun 2003 mengenai Keuangan Negara, Undang-undang Nomor 1 tahun 2004 mengenai Perbendaharaan Negara, \& Undang-undang Nomor 15 tahun 2004 mengenai Pemeriksaan Pengelolaan \& Tanggungjawab Keuangan Negara.

Media pelaporan akuntabilitas tadi merupakan Laporan Akuntabilitas Kinerja Instansi Pemerintah (LAKIP) adalah output berdasarkan suatu proses sistem akuntabilitas kinerja instansi pemerintah (SAKIP). Sistem Akuntabilitas Kinerja Instansi Pemerintah (SAKIP) adalah instrumen yg dipakai instansi pemerintah buat menjawab kewajiban tadi yg terdiri berdasarkan banyak sekali komponen yg adalah satu kesatuan, yaitu perencanaan stratejik, perencanaan kinerja, \& pelaporan kinerja. LAKIP yg berkualitas sangat krusial peranannya lantaran bisa memenuhi prinsip-prinsip akuntabilitas/pertanggungjawaban \& transparansi sebagai akibatnya bisa dilaporkan \& dipertanggungjawabkan sang instansi pemerintah sentra \& wilayah pada para stakeholders/pemangku kepentingan termasuk warga terhadap proses penyelenggaraan pemerintahan. Berdasarkan LAN \& BPKP (2000) LAKIP yg berkualitas wajib memenuhi prinsip-prinsip laporan yg baik yaitu menjadi berikut:

1. Relevance (relevan)

2. Accuracy/reliability (seksama \& handal)

3. Consistency/comparability (Konsisten/bisa diperbandingkan)

4. Verifiability/ traceability (Verifikasi/ditelusuri)

5. Timeliness (Tepat Waktu)

6. Understandability (Bisa dimengerti)

7. Mengikuti standart laporan yg ditetapkan sesuai menggunakan peraturan

Perundang-undangan yg berlaku.

8. Prinsip lingkup pertanggungjawaban

9. Prinsip prioritas

10. Prinsip manfaat

LAKIP Badan Pengelola Pajak \& Retribusi Daerah yg berkualitas sangat ditentukan dengan beberapa faktor pengelolaan keuangan wilayah misalnya sistem perencanaan pembangunan, penganggaran memakai aturan berbasis kinerja $(\mathrm{ABK})$, penatausahaan keuangan wilayah termasuk didalamnya mengatur mengenai prosedur pertanggungjawaban belanja, pelaporan \& pertanggungjawaban dan supervisi keuangan wilayah melalui audit intern. apabila variable-variabel tadi berjalan secara efektif maka LAKIP yg berkualitas akan tercapai.

Laporan Akuntabilitas Kinerja Instansi Pemerintah (LAKIP) dimulai menggunakan merancang \& memutuskan Sistem Akuntabilitas Kinerja Instansi Pemerintah (SAKIP) yg diawali berdasarkan suatu proses perencanaan yg strategik (Renstra) adalah dokumen perencanaan 5 (lima) tahun. Perencanaan stratejik adalah langkah awal yg wajib dilakukan supaya sanggup menjawab tuntutan lingkungan strategik lokal, nasional,\& global, \& permanen berada pada tatanan Sistem Administrasi Negara Kesatuan Republik Indonesia. Dokumen Rencana stratejik setidaknya memuat visi, misi, tujuan, sasaran, \& strategi (cara mencapai tujuan \& sasaran). Setelah itu instansi pemerintah wajib bias 
memutuskan dokumen perencanaan kinerja (Renja) yg adalah turunan berdasarkan perencanaan stratejik (renstra) instansi pemerintah yg akan dicapai pada 1 (satu) tahun.

Setelah proses penyusunan \& penetapan perencanaan stratejik \& perencanaan kinerja yg efektif dalam Badan Pengelola Pajak \& Retribusi Daerah akan dilanjutkan buat dianggarkan dalam Anggaran Penbisaan \& Belanja Daerah (APBD) menggunakan memakai pendekatan Anggaran Berbasis Kinerja (ABK), sebagai akibatnya penyusunan aturan SKPD menggunakan menyusun Rencana Kerja \& Anggaran (RKA) wajib memasukkan aktivitas \& acara yg sudah ditetapkan kedalam dokumen perencanaan kinerja bersama capaian indikator kinerja aktivitas berupa input (masukan), output (keluaran) \& outcome (hasil), Jika nir kualitas LAKIP yg akan dilaporkan akan rendah lantaran LAKIP yg akan disusun nanti tidak bisa diukur capaian kinerjanya, nir memenuhi prinsip-prinsip relevan \& mengikuti baku laporan yg ditetapkan sinkron menggunakan peraturan Perundang-undangan yg berlaku yg diatur pada SK LAN No.239/IX/6/8/2003 tahun 2003 mengenai Perbaikan Pedoman Penyusunan Laporan Akuntabilitas Kinerja Instansi Pemerintah (LAKIP).

Melalui sistem penganggaran berbasis kinerja ini penetapan besarnya alokasi aturan wilayah lebih mempertimbangkan nilai uang (value for money) \& nilai uang yg mengikuti fungsi (money follow function) sinkron menggunakan kebutuhan riil setiap unit kerja. Dengan memakai aturan berbasis kinerja maka setiap pemerintah wilayah akan diketahui kinerjanya. Penyusunan APBD berbasis prestasi kerja atau kinerja dilakukan berdasarkan capaian kinerja, indikator kinerja, analisis baku belanja, baku satuan harga, \& baku pelayanan minimal. Dalam penyelenggaraannya, pemerintah wilayah dituntut lebih responsif, transparan, \& akuntabel terhadap kepentingan masyarakat (Mardiasmo, 2006).

Terkait menggunakan peraturan tadi pada rangka berakuntabilitas menggunakan menyusun LAKIP Badan Pengelola Pajak \& Retribusi Daerah yg berkualitas, Badan Pengelola Pajak \& Retribusi Daerah Pemerintah Kota Medan tidak sanggup melepaskan kewajiban buat memenuhi ketentuan yg terdapat yaitu menciptakan \& mengungkapkan Laporan Akuntabilitas Kinerja Instansi Pemerintah (LAKIP) Badan Pengelola Pajak \& Retribusi Daerah.

Penyusunan Rancangan APBD pada Pemerintahan Kota Medan diawali menggunakan disusunnya RKA- Badan Pengelola Pajak \& Retribusi Daerah terlebih dahulu sehabis memperoleh batasan pagu aturan buat setiap Badan Pengelola Pajak \& Retribusi Daerah atas acara \& Aktivitas yg diusulkan dalam tahun bersangkutan. Batasan aturan yg wajib ditaati oleh Badan Pengelola Pajak \& Retribusi Daerah merupakan sebagaimana yg tertuang pada pada dokumen KUA \& PPAS yg sudah disepakati beserta antara eksekutif \& legislatif. Bappeda menjadi satuan kerja perencanaan pembangunan wilayah mempunyai kiprah yg sangat krusial pada penentuan acara \& Aktivitas yg akan dilaksanakan bagi Badan Pengelola Pajak \& Retribusi Daerah, hal ini dikarenakan wajib diselaraskannya antara usulan acara \& Aktivitas Badan Pengelola Pajak \& Retribusi Daerah menggunakan prioritas pembangunan wilayah sebagaimana yg tertuang pada pada dokumen perencanaan wilayah baik yg terdapat pada dokumen Badan Pengelola Pajak \& Retribusi Daerah yg adalah kompilasi berdasarkan dokumen perencanaan kinerja (Renja) Badan Pengelola Pajak \& Retribusi Daerah juga yg terdapat pada pada dokumen Rencana Pembangunan Jangka Menengah Daerah (RPJMD) yg 
pula adalah kompilasi berdasarkan dokumen perencanaan strategik (Renstra) Badan Pengelola Pajak \& Retribusi Daerah.

\section{LANDASAN TEORI \\ Anggaran Berbasis Kinerja}

Anggaran yang disusun dengan menghubungkan output atau hasil apa yang ingin dicapai, mengidentifikasi input, ouput, dan outcome yang dihasilkan dengan dilaksanakannya suatu aktivitas atau Aktivitas berdasarkan Peraturan Menteri Dalam Negeri No. 13 Tahun 2006 mengenai Pedoman Pengelolaan Keuangan Daerah.

\section{Pertanggungjawaban Belanja}

Bukti-bukti pengeluaran atas pelaksanaan suatu Aktivitas dan bukti pengeluaran selain Aktivitas seperti pembayaran gaji bisa dipertanggungjawabkan berdasarkan Peraturan Menteri Dalam Negeri No. 13 Tahun 2006 mengenai Pedoman Pengelolaan Keuangan Daerah.

Kualitas laporan akuntabilitas kinerja instansi pemerintah

Laporan akuntabilitas kinerja instansi pemerintah yang memenuhi prinsipprinsip pelaporan yang baik berdasarkan LAN dan BPKP (2000).

\section{METODE PENELITIAN}

Jenis Artikel yang direncanakan adalah Artikel kausal dengan pendekatan kuantitatif yaitu mengukur hubungan antara variabel riset, atau untuk menganalisis bagaimana pengaruh suatu variabel terhadap variabel lainnya (Umar, 2008). Populasi adalah wilayah generalisasi yang terdiri atas: obyek/subyek yang mempunyai kualitas dan karakteristik tertentu yang ditetapkan oleh peneliti untuk dipelajari dan kemudian ditarik kesimpulannya (Sugiyono, 2007). Populasi dalam Artikel ini adalah seluruh Badan Pengelola Pajak dan Retribusi Daerah yang ada di Pemerintah Kota Medan sebanyak 375 pegawai/responden.

Artikel ini menggunakan data primer berupa daftar pertanyaan atau kuesioner yang menggali persepsi dari pegawai Badan Pengelola Pajak dan Retribusi Daerah Pemerintah Kota Medan. Data diperoleh dengan cara meminta setiap pegawai Badan Pengelola Pajak dan Retribusi Daerah Pemerintah Kota Medan untuk mengisi kuesioner yang akan dibagikan. Data sekunder adalah data yang diperoleh atau dikumpulkan peneliti dari berbagai sumber yang telah ada. Dalam Artikel ini data penerimaan pajak diperoleh melalui buku teori, karya ilmiah, jurnal yang berhubungan dengan masalah yang diteliti.Dimana teknik pengumpulan data yang dilakukan melalui wawancara dan quisioner. Pengolahan data menggunakan perangkat lunak SPSS 16.0For Windows. Analisis statisitk inferensial dalam penelitian ini meliputi: uji asumsi klasik, regresi analisis jalur, uji hipotesis.

\section{HASIL DAN PEMBAHASAN}

Pengaruh Penerapan Anggaran Berbasis Kinerja Terhadap Kualitas Laporan Akuntabilitas Kinerja Instansi Pemerintah (LAKIP)

Hasil memberitahukan bahwa $t_{\text {hitung }} 9,403>t_{\text {tabel }} 1,665$ dan signifikan $0,000<0,055$, Maka penerapan aturan berbasis kinerja berpengaruh positif \& signifikan terhadap Kualitas Laporan Akuntabilitas Kinerja Instansi Pemerintah 
(LAKIP). Hasil Artikel ini sinkron menggunakan output Artikel Darawanis (2013), memperlihatkan bahwa penerapan aturan berbasis kinerja berpengaruh positif \& signifikan terhadap Kualitas Laporan Akuntabilitas Kinerja Instansi Pemerintah (LAKIP). Artikel ini menyatakan bahwa Anggaran Berbasis Kinerja merupakan sistem penganggaran yg berorientasi dalam "hasile organisasi \& berkaitan sangat erat terhadap Visi, Misi \& Rencana Strategis organisasi. Anggaran Berbasis Kinerja mengalokasikan sumberdaya dalam acara bukan dalam unit organisasi semata \& memakai "hasil measurement" menjadi indikator kinerja organisasi (Bastian, 2006).

Anggaran Berbasis Kinerja disusun selesainya melalui proses penyusunan \& penetapan perencanaan strategik \& perencanaan kinerja yg efektif dalam Badan Pengelola Pajak \& Retribusi Daerah akan dilanjutkan buat dianggarkan dalam Anggaran Penbisaan \& Belanja Daerah menggunakan memakai pendekatan Anggaran Berbasis Kinerja (ABK), sebagai akibatnya penyusunan aturan Badan Pengelola Pajak \& Retribusi Daerah menggunakan menyusun Rencana Kerja \& Anggaran (RKA) wajib memasukkan Aktivitas \& acara yg sudah ditetapkan ke pada dokumen perencanaan kinerja, Jika tidak kualitas LAKIP yg akan dilaporkan akan rendah tidak memenuhi prinsip-prinsip relevan \& mengikuti baku laporan yg ditetapkan sinkron menggunakan peraturan Perundang-undangan yg berlaku yg diatur pada SK LAN No.239/IX/6/8/2003 tahun 2003 tentang Perbaikan Pedoman Penyusunan Laporan Akuntabilitas Kinerja Instansi Pemerintah (LAKIP).

\section{Pengaruh Pertanggungjawaban Belanja Terhadap Kualitas Laporan Akuntabilitas Kinerja Instansi Pemerintah (LAKIP)}

Hasil menunjukkan bahwa $t_{\text {hitung }} 1,056>t_{\text {tabel }} 1,665$ dan signifikan $0,294>$ 0,05, Maka pertanggungjawaban belanja positif \& nir berpengaruh signifikan secara parsial terhadap Kualitas Laporan Akuntabilitas Kinerja Instansi Pemerintah (LAKIP) Hasil Artikel ini sinkron menggunakan output Artikel Darawanis (2013), memperlihatkan bahwa penerapan aturan berbasis kinerja berpengaruh positif \& signifikan terhadap Kualitas Laporan Akuntabilitas Kinerja Instansi Pemerintah (LAKIP). Artikel ini menyatakan bahwa Pertanggungjawaban belanja wajib memenuhi prinsip-prinsip bukti pengeluaran yg lengkap \& absah sebagai akibatnya mampu dipertanggungjawabkan atau diuji secara formil \& materil, sebagai akibatnya dalam ketika penyusunan LAKIP Badan Pengelola Pajak \& Retribusi Daerah data bersifat seksama \& mampu diuji kebenarannya.

\section{KESIMPULAN}

Berdasarkan hasil penelitian yang dilakukan disimpulkan bahwa penerapan anggaran berbasis kinerja secara parsial berpengaruh positif dan signifikan terhadap Kualitas Laporan Akuntabilitas Kinerja Pegawai Instansi Pemerintah (LAKIP), sedangkan pertanggungjawaban belanja secara parsial berpengaruh positif dan tidak signifikan terhadap Kualitas Laporan Akuntabilitas Kinerja Instansi Pemerintah (LAKIP) Badan Pengelola Pajak dan Retribusi Daerah Pemerintah Kota Medan. Sedangkan penerapan anggaran berbasis kinerja dan pertanggungjawaban belanja secara simultan berpengaruh positif dan signifikan terhadap Kualitas Laporan Akuntabilitas Kinerja Pegawai Instansi Pemerintah (LAKIP) Badan Pengelola Pajak dan Retribusi Daerah Pemerintah Kota Medan. 


\section{REFERENSI}

Bastian, Indra (2006), Sistem Akuntansi Sektor Publik, Edisi: 2, Salemba Empat, Jakarta.

Darwanis, Sephi Chairunnisa. (2013). Akuntabilitas Kinerja Instansi Pemerintah. Universitas Syiah Kuala Aceh. Jurnal Telaah \& Riset Akuntansi. Vol.6. No.2 Juli 2013. Hlm.150-174.

Departemen Dalam Negeri (2002). Keputusan Menteri Dalam Negeri Nomor 29 Tahun 2002 mengenai Pedoman Pengurusan, Pertanggungjawaban dan Pengawasan Keuangan Daerah Serta Tata Cara Penyusunan Anggaran Penbisaan dan Belanja Daerah, Pelaksanaan Tata Usaha Keuangan Daerah dan Penyusunan Perhitungan Anggaran Penbisaan dan Belanja Daerah, Jakarta.

Departemen Dalam Negeri (2006). Peraturan Menteri Dalam Negeri Nomor 13 Tahun 2006 mengenai Pedoman Pengelolaan Keuangan Daerah, Jakarta.

Erlina (2008). Metodologi Artikel Bisnis untuk Akuntansi dan Manajemen, USU Press, Medan.

Herawati, Tuti. (2014). Pengaruh Sistem Pengendalian Intern Terhadap Kualitas Laporan Keuangan (Survei Pada Organisasi Perangkat Daerah Pemda Cianjur). STIE STEMBI - Bandung. ISSN : 1693-4482. STAR - Study \& Accounting Research | Vol XI, No. 1 - 2014.

Kementerian Aparatur Negara dan Reformasi Birokrasi (2012). Permenpan dan RB No. 25 Tahun 2012 mengenai Petunjuk Pelaksanaan Evaluasi Akuntabilitas Kinerja Instansi Pemerintah.

Kuncoro, Mudrajad, (2008). Metode Riset untuk Bisnis dan Ekonomi, Erlangga, Jakarta.

Lembaga Administrasi Negara (LAN) dan Badan Pengawas Keuangan dan Pembangunan (BPKP) (2000). Modul Sosialiasi Sistem Akuntabilitas Kinerja Instansi Pemerintah (AKIP), Jakarta.

Lembaga Administrasi Negara (LAN) (2003). SK LAN No. 239/IX/6/8/2003 tahun 2003 mengenai Perbaikan Pedoman Penyusunan Laporan Akuntabilitas Kinerja Instansi Pemerintah (LAKIP), Jakarta.

Lubis, Ade Fatma (2007). Aplikasi SPSS untuk Penyusunan Skripsi dan Tesis, USU Press, Medan.

Mardiasmo (2006). Perwujudan Transparansi dan Akuntabilitas Publik Melalui Akuntansi Sektor Publik: Suatu Sarana Good Governance, Jurnal Akuntansi Pemerintah, Vol. 2. No.1.

Sugiyono (2007). Metode Artikel Bisnis, Alfabeta, Bandung.

Syarifudin, Akhmad. (2014). Pengaruh Kompetensi SDM dan Peran Audit Intern terhadap Kualitas Laporan Keuangan Pemerintah Daerah dengan Variabel Intervening Sistem Pengendalian Internal Pemerintah (studi empiris pada Pemkab Kebumen). STIE Putra Bangsa Kebumen. Jurnal Fokus Bisnis, Volume 14, No 02, bulan Desember 2014. 